студентів з вектору освоєння національних культурних здобутків у вектор педагогічної діяльності; методи, які застосовують у різних видах діяльності на уроках музичного мистецтва (хоровий спів, музично-ритмічна діяльність, слухання музичних творів, імпровізація, гра на музичних інструментах тощо), однак, їх опрацювання має бути спрямовано на розкриття етнопедагогічного й культурного потенціалу народного і національного мистецтва; методи, що спрямовані на активізацію емоційного відгуку учнів у процесі сприймання народно-пісенної творчості, на формування художньо-естетичних, ціннісних та моральних якостей учнів; методи, що дозволять інтегрувати, узагальнювати, презентувати опрацьований матеріал.

UDC 378.018.54.091.2:784.071.2](510+477)(043.3)

\author{
Zhang Lianhong \\ Sumy State Pedagogical University \\ named after A.S. Makarenko \\ ORCID ID 0000-0002-7416-3705
}

DOI 10.24139/2312-5993/2020.09/500-512

\title{
DEVELOPM ENT OF VOCAL TRADITIONS IN CHINA AND UKRAINE: HISTORICAL CONTEXT
}

The article reveals the features of vocal traditions development in China and Ukraine in the historical context. The stages of vocal traditions development in China and Ukraine are outlined. The essential characteristics of vocal traditions at each stage of development in the studied countries are defined. The comparative analysis of both vocal traditions enabled defining the main differences and the common features in the development of the studied phenomenon. The differences lie in the fact that Ukrainian vocal tradition has been constantly improving, while Chinese - has experienced periods of decline; in China the basis of vocal training is philosophical, while in Ukraine - spiritual. The common features include implementation of foreign experience in the content of vocal education and training of vocalists in various fields - academic and folk, as well as the spread of pop singing.

Key words vocal traditions, development, historical context, China, Ukraine.

Introduction. China and Ukraine are the countries, where vocal art is traditionally highly valued, and training of highly qualified vocalists is one of the priorities for the development of higher music education.

Today, vocal art in China is far ahead of its theoretical understanding. Professional vocal training, its pedagogical support, performing abilities of students-vocalists and processes of their realization today have some contradictory pedagogical approaches that complicates organization of educational work in this sphere. In Ukraine, vocal training is constantly developing, taking into account the challenges of the XXI century.

In order to better understand the modern state of vocal training in both countries, we think it is necessary to study their vocal traditions in historical context. 
Analysis of relevant research. Different aspects of vocal training development have been studied by such Chinese and Ukrainian researchers as Xu Hailin, Shi Weizheng, Cao Yanli, Chen Xihai, Sun Peiting, Wang Bingzhao, Wang Yuine, Zhang Hao, Zhang Xiong, Lin Lin (China), V. Bahadurov, V. Bilichenko, B. Hnyd, L. Hryn, Yu. Hryshchenko, D. Yevtushenko, V. Ivanov, A. Kozytskyi, M. Lvov, O. M ykhailychenko, I. Nazarenko, O. Sleptsova, M. Yarova and others (Ukraine).

At the same time, we haven't found the studies, which would comprehensively reveal the genesis of vocal traditions in Ukraine and China.

Taking into account the above mentioned, the aim of the article is to reveal the features of vocal traditions development in China and Ukraine in the historical context.

Research methods. To reach the desired objectives, the method of diachronic-comparative and synchronous-comparative analysis of literary sources and official documents was used, that enabled singling out the stages of development of the studied phenomenon in China and Ukraine and giving characteristics of the main changes in both countries.

Research results. Determining the peculiarities of vocal traditions development in China and Ukraine involves identifying the corresponding stages, which highlight the essential changes, that occurred in the studied phenomenon.

The criteria for distinguishing the stages of vocal traditions development in both countries are the following:

1) historical context;

2) leading socio-cultural conditions;

3) influence of socio-political factors;

4) internal patterns of development of vocal art specialists training in the system of higher music education.

Diachronic-comparative and synchronous-comparative analysis of a significant number of primary sources, namely normative documents, scientific publications has allowed to state that the stages of development of the studied process in China are as follows:

Stage 1 (II millennium BC - XIII century BC) - birth;

Stage 2 (XIV-XI centuries BC - XIII centuries AD) - formation;

Stage 3 (XIV - late XIX century) - traditional;

Stage 4 (early XX century - 20-30s of the XX century) - massovization;

Stage 5 (1937-1949) - professionalization;

Stage 6 (1949-1965) - institutionalization;

Stage 7 (1966-1976) - decline; 
Stage 8 (1976-1990) - reformation;

Stage 9 (from 1990 - to the present) - modern.

Accordingly, in Ukraine, formation and development of vocal traditions took place in the following stages:

Stage 1 (up to the IX century) - prehistoric;

Stage 2 (IX-XV centuries) - emergence;

Stage 3 (XVI-XVII centuries) - reformation;

Stage 4 (XVIII century) - enlightenment;

Stage 5 (first half of the XIX century) - academic;

Stage 6 (late XIX - early XX centuries) - professional;

Stage 7 (1920s-1980s) - theoretical;

Stage 8 (90s of the XX century - early XXI century) - modern.

Periodization of professional vocal education development in China and Ukraine is presented in Table 1.

Table 1

Development of professional vocal education in China and Ukraine

\begin{tabular}{|l|l|}
\hline \multicolumn{1}{|c|}{ China } & \multicolumn{1}{c|}{ Ukraine } \\
\hline birth (II millennium BC - XIII century BC) & prehistoric (up to the IX century) \\
\hline $\begin{array}{l}\text { formation (XIV-XI centuries BC - XIII } \\
\text { centuries AD) }\end{array}$ & emergence (IX-XV centuries) \\
\hline traditional (XIV - late XIX century) & reformation (XVI-XVII centuries) \\
\hline $\begin{array}{l}\text { massovization (early XX century - 20-30s of } \\
\text { the XX century) }\end{array}$ & enlightenment (XVIII century) \\
\hline professionalization (1937-1949) & academic (first half of the XIX century) \\
\hline institutionalization (1949-1965) & professional (late XIX- early XX centuries) \\
\hline decline (1966-1976) & theoretical (1920s-1980s) \\
\hline reformation (1976-1990) & $\begin{array}{l}\text { modern (90s of the XX century - early XXI } \\
\text { century) }\end{array}$ \\
\hline modern (from 1990 - to the present) & \\
\hline
\end{tabular}

Below, we'll describe the characteristics of the essential features of each of the outlined stage in each country. First of all, let's turn to determining the features of the historical development of the vocal tradition of China.

It is believed that the history of vocal education in China is less than a hundred years old. Note that vocal, as a specialty, is associated with work in conservatories and opera houses. However, Chinese researcher Xu Hailin points out that Western-style opera appeared in China relatively recently, so some researchers date the history of vocal education in China only to the end of the XIX century (Xu Hailin, 1997).

It seems to us that this point of view is superficial, as the criterion is vocal education of the conventional "Western type", and therefore it is noted that in 
ancient and medieval China, vocal professional education as such did not exist. However, the analysis of scientific sources on the problem under investigation testifies to the inaccuracy of this interpretation.

However, in the process of studying this issue, we can say with confidence that the vocalist profession in China was formed in antiquity, namely since the Shang dynasty (XIV-XI centuries BC). Note that in China, Kalne, there already were professional education institutions, which eventually became the world-famous music academies "Yue Fu", "Li Yuan", "Tai Chan Shu" and others. Thus, it is undeniable that development of vocal professional education in China has lasted for more than 3,000 years, inheriting the best national traditions.

In addition, it is believed that Chinese civilization is one of the oldest, has a long and rich history of about 5,000 years. During this period, formation of the Chinese ethnos, Chinese civilization, which has a special mentality and traditions passed down from previous to next generation. Therefore, focusing on traditions that in some cases are even supported at the state level, in China, quite early, in our opinion, began to form a system of education in general and music in particular.

In the context of considering the historical development of vocal professional education, in our opinion it should be emphasized that in ancient times Chinese music was not only instrumental but also vocal. It seems interesting to us that in the Bronze Age, at a time when there was a collapse of the oldest state formation into separate small states, the prevailing opinion was that every head of state must be as well versed in music as and in public affairs. Thus, prototypes of modern conservatories were created, which were considered the first professional music education institutions. Among them, the most important and widespread were High School (Tak Xue) and Junior School (Xiao Xue).

In the context of considering the first stage of professional vocal education development in China, we note that it reached its peak during the reign of the Tang Dynasty (618-907). Tai Chang Shu School became the leading institution of professional vocal education. Significantly, the emperors of this dynasty attached great importance to the arts and especially music, so Tai Chang Shu employed many musicians - 11549 people who danced and sang. Vocal teachers were then called "Doctors". Their system of education was divided into high, medium and low levels. And every ten years, all Tai Chang Shu teachers took a serious exam to prove their professional qualifications. A teacher who passed the examination tests received the position of an official. If they didn't pass the exam, they could get another chance in five years. The 
students had a period of study of fifteen years. During this period, they passed twelve exams - five difficult exams and seven intermediate exams. Students who passed these exams were given the opportunity to become teachers of Tai Chang Shu. In the case of poor student education, they were entitled to receive only a third of the salary after graduation (Chen Xihai, 1995, p. 121-148).

Thus, we can say that the vocalist profession in China was formed in antiquity.

Within the framework of this study we also consider it necessary to note that in ancient China vocalists training was based on philosophical and ideological ideas about the relationship between art and the spiritual world of man, the integrity and harmony of physical, mental and spiritual forces as a basis for high vocal performance. It should be noted that the sources of vocal creativity in China were folk songs and dances. It was believed that the unity of singing and dancing should be observed in the process of complex performance, and in vocal performances it was obligatory to use special looks and gestures, which with one or another degree of conventionality expressed feelings and emotions.

An analysis of the scientific literature has shown that further development of Chinese vocal art is linked to traditional Chinese opera. The Beijing Jinxi M usic and Drama Theater (Peking Opera) in the national literature, is an ancient theater of classical Chinese drama. It should be noted that it still has the status of a national cultural heritage. We note that the Peking Opera arose from the merging of a number of local theatrical genres, as a result of which it combined high performance technique and literary language wenyan with dynamic battle scenes and circus tricks.

We are convinced that the knowledge of vocal education traditions of ancient China contributed to the development of modern vocal professional education, as these traditions have been preserved in modern society. At the same time, they were combined with Western professional traditions. As a result, a modern Chinese vocal school was formed.

Considering the historical development of professional vocal education in China, we came to the conclusion that an important period is the $20-30$ s of the XX century. A landmark event for this was Japan's victory in the Sino-Japanese War in 1894. In this regard, the Chinese government decided to send Chinese students to study in Japan in order to better understand and gain experience, including professional education, in order to withstand the onslaught of Japan. As a result, a significant number of youths became students of various specialties of Japanese education institutions. 
Early XX century was marked by the return of some Chinese music students from Japan, who became the developers of educational material based on foreign and Chinese songs and the founders of a new system of vocal education in schools.

Analysis of the scientific literature on the problem under investigation, allowed to identify the main points of modern vocal professional education formation in China in the 20-30s of the XX century, namely:

1. The emergence of Russian music professional schools in China. It is believed that modern Chinese vocal art was borrowed from Russia. In the late XIX and early XX centuries, Russian vocal art spread in Harbin, where Russian musicians founded several professional music schools: in 1921, Harbin Higher Music School № 1, in July 1925 - Higher Music School named after A. K. Hlazunov. In 1927, Russian musicians together with the Orthodox Church opened a music training center (Zhang Hao, 2011).

2. Emergence of national Chinese professional music schools. The main factors in the rapid development of vocal professional education are the following: the return of Chinese students who have studied abroad to their homeland; strengthening of teaching staff; improving the quality of vocal training; opening of new professional music education institutions; arrival of new foreign specialists (Zhang Wei, 2005).

In the 1930s, a large number of music schools organized concerts of vocal music in order to promote it and draw attention to new art (Zhang Golian, 2006, p. 254-257).

1937-1949 were characterized by significant difficulties for higher music education institutions. The reason for this was historical events, namely the war with Japan (1937-1945) and the Chinese Civil War (1946-1949). During the war, some institutions were forced to either reduce the duration of training, or close altogether. However, as a result of studying the scientific literature, Song Jinan noted that despite this, new music schools, faculties and specialties still appeared. Thus, it is safe to say that the war hindered the development of vocal professional education, but, at the same time, it partly acted as a catalyst for its development (Song Jinan, 2012, p. 234-242).

The next stage in the formation of the Chinese vocal school lasted from 1949 to 1976. At this time, the Chinese government established HEls, which led to more favorable conditions for vocal professional education. At the same time, there were qualitative and quantitative improvements of the teaching staff of the HEls. As Xi Xiyuan noted, in 1966-1976 there was a cultural revolution, which had a significant impact on vocal education (Xi Xiyuan, 2004). 
Based on the analysis of the scientific literature (Yao Wei, 2014), we have identified the following main features in the development of the vocal education system in this period: 1 . Increasing the number of music universities and faculties, which created favorable conditions for the development of vocal education. 2. Obtaining the status of a conservatory by some music institutions (Shenyang, Sichuan and Xi'an). Later, the Tianjin Conservatory and the Chinese Conservatory were established. 3. The emergence of Chinese national pedagogical materials authored by Chinese scholars. Adaptation of vocal professional education to the national Chinese mentality and cultural peculiarities. 4. Establishment by the Chinese government of a number of professional music organizations, such as the Central Song and Dance Ensemble, the Central Symphony Orchestra, the Central Experimental Theater, the Central National Song and Dance Ensemble, and others. 5. Organization by the Chinese government of various levels of music festivals to raise the level of musical art. 6. Establishing musical ties with the countries of Eastern Europe and East and South Asia, which were manifested in the touring trips of music groups from China to these countries and vice versa. 7. Focus on the experience of the USSR in the organization of higher music education, including vocal artists training. 8. Admission to the teaching staff of Chinese HEls graduates. 9. Prohibition of any vocal pedagogical activity in 1966-1976.

The period from 1979 to the present day has been a time of transformation. At this time, the concert activities of Chinese artists stimulated the development of vocal professional education. This was especially noticeable in the 1980s and 1990s, when Chinese singers often won prizes in various international competitions.

Moving on to consideration of Ukrainian vocal education traditions, we can state that Ukrainian vocal pedagogy has undergone a multifaceted development. It originated from parish and monastery schools, as well as schools in the Zaporozhian Sich. In these education institutions it was mandatory to study musical disciplines, including vocal training. It can be explained by the fact that the latter has always been associated with religious worship. Ukrainian musicologists are convinced that the tradition of teaching church singing played a major role in the formation of vocal art in Ukraine and became an important factor that contributed to the development of national musical culture. Note that church singing in Kievan Rus, as well as the traditions of its teaching are considered an important component of culture and education. Thus, V. Ivanov, who studied the peculiarities of teaching church singing, argues that it is one of the mysteries of history, due to "the complexity 
of combining vocal and verbal principles, and with them the corresponding writing" (Ivanov, 1997, p. 5).

It is determined that the basis of Ukrainian professional vocal school formation is singing of church services in Kievan Rus. We owe the appearance of church singing in Kievan Rus to the first Byzantine and Bulgarian bearers of its traditions. I. Liashenko, whose subject of scientific works was formation of professional music education, called church singing "the epicenter of song singing" (Liashenko, 1998, p. 3).

According to V. Ivanov, the emergence of vocal education in Kievan Rus was also caused by introduction of Christianity. The scholar claimed that the wave of Christian culture brought with it written and vocal education in Rus. M oreover, together with Christian teaching, Ukrainian vocal education received a developed system of complex notation, a new method of learning vocal material and its implementation in practice, both performing and pedagogical (Ivanov, 1997, p. 10).

Emergence of Ukrainian vocal school of singing dates back to the IX-XV centuries. At this time, the process of educating the first musicians began, who later taught singing to young people. It is a well-known fact that vocal training during this period was carried out by ear, as there were no manuals. Teachers of singing passed on their knowledge to students orally, and the theoretical material was supported and illustrated by their own singing. It should be also stressed that training didn't have systemic character and took place only when it was necessary to replenish church or princely choirs with new singers.

XVI-XVII centuries were marked by improvement of musical-theoretical training of performers. For this purpose, Ukrainian teachers used the best achievements of Western European and national music culture. As a result, the vocal training system reached a high level. At this time, the name of Mykola Diletsky, whose musical-theoretical treatises became popular, became important. The author not only generalized the experience of contemporary music culture, but also laid the foundations of professional music pedagogy. At the same time, in his works we find useful and important information on preserving the singing voice, working on breathing, mastering singing in unison, educating youth by means of musical art. In addition, his treatises contained valuable theoretical and practical experience in teaching vocals.

In the second half of the XVII and XVIII centuries, the Kyiv-Mohyla Academy was recognized as one of the leading centers of Ukrainian cultural and musical life. It is a well-known fact that one of the compulsory subjects in this education institution was music together with other basic sciences. In 
addition, a music exam was required at the Academy. Note also that music was not just an academic discipline, but also an integral part of all the celebrations that took place in the institution. In this regard, the Kyiv-M ohyla Academy has a well-organized system of teaching singing, including choral. Since the 50 s of the XVII century, rector L. Baranovych organized a special music and choral school.

In the context of considering the historical development of Ukrainian vocal school, it's necessary to note that in the second half of the XVII - XVIII centuries the centers of national musical culture were the estates of hetmans and Cossack officers, in which there were musical groups. Such groups performed various musical compositions, vocal works (chants, psalms, part concerts), as well as new forms of European music-making.

During the study period, there were also choirs in most monasteries of Ukraine, which taught everyone who wanted to learn music. In addition, in the formation and development of the vocal school of Ukraine a significant role was played by the bishop's schools, which trained church singers. At this time, also began to actively develop folk-song creativity.

As for Ukrainian professional music, in the second half of the XVII - XVIII centuries a new choral genre appeared - the part concert. Subsequently, the one-part concert was replaced by a cyclical spiritual concert, which was caused by the influence of the Western European professional music.

Thus, the leading trends in the development of vocal education in Ukraine in the period under investigation were identified: reorientation of Ukraine's cultural ties from Byzantium to Western Europe; monophonic monody singing was replaced by polyphonic singing; dominance of the spiritual over the secular; combination of medieval, renaissance and baroque features.

The first half of the XIX century was marked by transition of the education system from a purely ecclesiastical to secular. This transition of the education system contributed to the combination of religious and secular forms of education: choral and solo singing, church singing in churches, conductor-choir and concert-performance activities, participation in literary and musical evenings.

The leading trend in the development of vocal education in the late XIX early XX century is its structuring in four areas, such as: 1) general vocal-choral education, which can be obtained at school, gymnasium, private boarding house; 2) vocal-choral education of teachers, which was provided by teachers' seminaries, institutes, various courses, women's higher pedagogical courses; 3) special vocal education, which was provided in music school, courses, private special music institutions, as well as in the Music and Drama School of M. Lysenko); 4) professional vocal education provided by music colleges, conservatories. 
The next period (1920s-1980s) was marked by active development of vocal traditions in Ukraine. Thus, the 1920s became the most intense for the development of Ukrainian music, including vocal. We can observe creation of opera houses, philharmonics in large cities. The young composers of that time set themselves the goal of making Ukrainian music non-provincial, vocally diverse.

The 1930s were marked by the development of Ukrainian musical science. Thus, we observe an increase in the creative level of musical culture, including vocal, which led to the theorizing of vocal education, the emergence of musicological works. It should be noted that such work was actively carried out at the Institute of Ukrainian Folklore of the Academy of Sciences, at the departments of history and music theory of the Kyiv and Lviv conservatories. Employees of these institutions collected recordings of Ukrainian folk songs, developed a number of theoretical issues of folk art, published scientific papers, made a large collection of gramophone records, wrote monographs (Huralnyk, 2015).

The 1950s of the XX century became the starting point for the creation of manuals on all types of musical activities, including vocal, emergence of a large number of methodological developments, activation and dissemination of scientific, pedagogical and musicological research (Huralnyk, 2015).

In the 1960s and 1980s, it was the beginning of the idea of training music and singing teachers at pedagogical institutes (later universities) of Ukraine, namely at music-pedagogical departments. In this regard, appropriate curricula and programs were formed, and thus, general secondary education institutions received highly qualified musicians (Huralnyk, 2015).

In addition, active development of the classical academic vocal school continues. As a result of the analysis of scientific works and activities of leading art education institutions, we can say about the renewal of the vocal academic school of Ukraine and at the same time about preservation of its national basis. During this period, the vocal school, in addition to academic, was characterized by emergence of other areas of vocal, namely pop and folk. We also emphasize the heterogeneity of academic vocals, in particular its classical-romantic and modern (avant-garde) types.

The current stage of development of the vocal tradition in Ukraine continues to be active and at the same time allows for the expansion of horizons. It is believed that the center of the modern Ukrainian vocalpedagogical school is Kyiv.

Today Ukrainian National Tchaikovsky Academy of Music has two vocal departments - solo and chamber singing. There are also other centers in Kyiv where academic singing is actively developing. Among such institutions is the 
National Academy of Management of Culture and Arts, as well as music colleges and art schools.

Thus, at the present stage of vocal traditions development in Ukraine, the vocal-pedagogical school is at the stage of transformation in accordance with the socio-cultural challenges of the XXI century. This period is defined as active, which is characterized by a surge in the development of national culture.

Conclusions and prospects for further research. Thus, we can say with confidence that the Ukrainian vocal tradition as well as the Chinese one has undergone a long multifaceted development. As a result of a comparative analysis of both vocal traditions, we note that the main differences are that the Ukrainian vocal tradition has been constantly improving, and the Chinese - has experienced periods of decline; philosophical basis of vocal training in China and spiritual basis of vocal training in Ukraine. And the common features include implementation of foreign experience in the content of vocal education and training of vocalists in various fields - academic and folk, as well as the spread of pop singing.

\section{REFERENCES}

Гуральник, Н. П. (2015). Історія музичної освіти України: курс лекцій для студентів музичних спеціальностей вОз мистецького спрямування. Київ (Huralnyk, N. P. (2015). History of music education in Ukraine: a course of lectures for students of music specialties of the HEls of art direction. Kyiv).

Іванов, В. Ф. (1997). Навчання церковного співу в Україні у IX-XVII cm. К.: Муз. Україна (Ivanov, V. F. (1997). Teaching church singing in Ukraine in the IX-XVII centuries. K.: Musical Ukraine).

Ляшенко, І. Ф. (1998). Музична україністика в світлі сучасної культурної політики: аспекти гуманізації та гуманітаризації національної освіти. Українське музикознавство, Вип. 28: Музична україністика в контексті світової культури, 3-8 (Liashenko, I. F. (1998). Musical Ukrainian Studies in the Light of Modern Cultural Policy: Aspects of Humanization and Humanitarianization of National Education. Ukrainian Musicology, Vol. 28: Musical Ukrainian Studies in the Context of World Culture, 3-8).

Си Сюань (2004). История культурной революции в Китае. Пекин (на китайском языке) (Xi Xuan (2004). History of the Cultural Revolution in China. Beijing (in Chinese)).

Сун Цзинан (2012). История музыкального образования в Китае (1840-2000). Шанхай (на китайском языке) (Song Jinan (2012). History of M usic Education in China (18402000). Shanghai (in Chinese)).

Сю Хайлин (1997). Педагогическая деятельность и теория традиционной оперы в древнем Китае. Музыкальное искусство, 3, 58-64 (на китайском языке) (Xu Hailing (1997). Teaching Activities and Theory of Traditional Opera in Ancient China. M usical Art, 3, 58-64 (in Chinese)).

Чжан Голян (2006). Генезис, развитие и тенденции распространения наук в Китае. Новости развития, 2, 14-18 (на китайском языке) (Zhang Golyan (2006). Genesis, development and trends in the spread of sciences in China. Development News, 2, 1418 (in Chinese)). 
Педагогічні науки: теорія, історія, інноваційні технології, 2020, № 9 (103)

Чжан Хао (2011). Влияние русского вокального искусства на Харбин. Северная музыка, 1, 9-10 (на китайском языке) (Zhang Hao (2011). The influence of Russian vocal art on Harbin. Northern Music, 1, 9-10 (in Chinese)).

Чэн Сыхай (1995). История музыки древнего Китая. Пекин: Издательство международная культура (на китайском языке) (Cheng Sihai (1995). The history of the music of ancient China. Beijing: International Culture Publishing House (in Chinese)).

Яо Вэй (2014). Развитие вокального профессионального образования в Китае в период 1937-1949 гг. Международная школа психологии и педагогики, 5, 96-97 (Yao Wei (2014). The development of vocal vocational education in China in the period 19371949. International School of Psychology and Pedagogy, 5, 96-97).

\section{PEЗЮME}

Чжан Лянхун. Развитие вокальных традиций в Китае и Украине: исторический контекст.

В статье раскрываются особенности развития вокальных традиций Китая и Украины в историческом контексте. Обозначены этапы развития вокальных традиций Китая и Украины. Определены сущностные характеристики вокальных традиций на каждом этапе развития в исследуемых странах. Сравнительный анализ обеих вокальных традиций позволил определить основные отличия и общие черты в развитии изучаемого явления. Отличия заключаются в том, что украинская вокальная традиция постоянно совершенствуется, а китайская переживает периоды упадка; в Китае основа вокального обучения - философская, а в Украине - духовная. Общими чертами являются внедрение зарубежного опыта в содержание вокального образования и подготовки вокалистов в различных областях - академической и народной, а также распространение эстрадного пения.

Ключевые слова: вокальные традиции, развитие, исторический контекст, Китай, Украина.

\section{АНОТАЦІЯ}

Чжан Лянхун. Розвиток вокальних традицій в Китаї та Україні: історичний контекст.

Статтю присвячено висвітлнню особливостей розвитку вокальних традицій Китаю та України. На основі низки критеріїв (історичний контекст; провідні соціокультурні умови; вплив соціально-політичних факторів; внутрішні закономірності розвитку підготовки спеціалістів вокального мистецтва в системі вищої музичної освіти) виокремлено етапи розвитку досліджуваного феномену в обох країнах. У Китаї розвиток вокальних традицій відбувався протягом таких етапів: 1 етап (II тис. до н.е. XIII cm. до н.е.) - зародження; 2 етап (XIV-XI cm. до н.е. - XIII cm. н.е.) - становлення; 3 етап (XIV - кінець XIX cm.) - традичійний; 4 етап (початок XX cm. - 20-30-і роки XX cm.) масовізації; 5 етап (1937-1949 рр.) - продесіоналізації; 6 етап (1949-1965 рр.) інституціоналізації; 7 етап (1966-1976 рр.) - занепаду; 8 етап (1976-1990рр.) реформації; 9 етап (з 1990 року по теперішній час) - сучасний.

В Україні становлення та розвиток вокальних традицій відбувалося за такими етапами: 1 етап - доісторичний (до IX століття); 2 етап - зароджувальний (IX XV століття); 3 етап - реформаційний (XVI - XVII столітmя); 4 етап - просвітницький (XVIII століття); 5 етап - академічний (I половина XIX століття); 6 етап - професійний (кінець XIX - початок XX столітта); 7 етап - теоретичний (1920 - 80-і рр.); 8 етап сучасний (90-і рр. XX сm. - початок XXI cm.).

Констатовано, що українська вокальна традиція, так само як і китайська, пройшла тривалий багатоаспектний розвиток. У результаті порівняльного аналізу 
обох вокальних традицій виявлено, що основними відмінностями є те, що українська вокальна традиція розвивалася, постійно удосконалюючись, а китайська - зазнавала періодів занепаду; основа вокальної підготовки в Китаї $\epsilon$ філософською, тоді як в Україні - духовною. До спільних рис віднесено імплементачію зарубіжного досвіду у зміст вокальної освіти та підготовки вокалістів із різних напрямів - академічного й народного, а також поширення естрадного співу.

Ключові слова: вокальні традиції, розвиток, історичний контекст, Китай, Україна.

\title{
UDC 378.018.54.091.2:780.616.433.071.2](510)(043.3)
}

\author{
Iryna Chystiakova \\ Sumy State Pedagogical University \\ named after A.S. Makarenko \\ ORCID ID 0000-0001-8645-510X \\ Wang Boyuan \\ Sumy State Pedagogical University \\ named after A.S. Makarenko \\ ORCID ID 0000-0001-8851-6156 \\ DOI 10.24139/2312-5993/2020.09/512-523
}

\section{WAYS OF THE PIANISTS-PERFORM ERS TRAINING IM PROVEM ENT IN ART INSTITUTIONS OF HIGHER EDUCATION OF CHINA}

Based on the analysis of the existing problems, the article highlights the ways of improving the pianists-performers training in art institutions of higher education in China. The main recommendations that will help improve the quality of pianists-performers training in art institutions of higher education, include: increasing the level of music-theoretical knowledge, historical thinking and auditory experience of European music perception by students; improving the mechanism of performance mastering of the sound space by musicians; forming students' ideas about musical drama; guiding students' independent work through special tasks aimed at expanding the artistic worldview, the general thesaurus; developing and creating a specialized resource on the Internet to promote advanced methods of training pianists.

Key words pianists-performers, training of pianists-performers, art institutions of higher education, China.

Introduction. At the present stage of society development, higher music education occupies an increasingly important place in the field of cultural achievements of developed countries. It is an indisputable fact that the art of music opens wide opportunities for interaction between countries and peoples in the field of culture, which is confirmed by the popularity, demand and prestige of international music competitions. Thus, training of pianistsperformers at a level that meets modern requirements, allows to solve important socio-cultural problems.

Analysis of relevant research. Theoretical and practical foundations of pianists-performers training in art institutions of higher education in China 